\title{
KNOWLEDGE SHARING-BASED STRATEGIC ROLES OF SUBSIDIARIES OF MULTINATIONALS IN CHINA
}

\author{
S. T.C. Amarasinghe ${ }^{1}$ and M. Yunshi ${ }^{1}$
}

\begin{abstract}
In this study, multinational enterprise was conceptualized as an integrative unit for making localized knowledge global. Knowledge base of a Multi National Corporation was basically categorized into two groups; local and global knowledge according to accessibility of corporate units to the knowledge of the corporation rather than its location. It is argued that strategic roles of subsidiaries within the same MNC can differ in terms of magnitude and nature of involvement in sharing with the global knowledge base of the corporation. The paper moves away from the unidirectional flow of knowledge. Based on the knowledge sharing patterns, a four-cell classification matrix was developed to illustrate different strategic roles of subsidiaries. The cluster analysis revealed that there is a significant inter-subsidiary difference in knowledge sharing patterns of subsidiaries. The study shows the strategic active subsidiary as a special case of the problems of managing spatially separate knowledge sources.
\end{abstract}

Key words: Strategic Roles, Multinationals, Knowledge sharing

\section{INTRODUCTION}

In recent years, inter-organizational competition has not only intensified, its nature has fundamentally changed: it has become more knowledge based, and the sources of competitive advantage have shifted unmistakably from physical assets to intellectual resources (Prahalad and Hamel, 1990; Quinn, 1992; Stewart, 1997). While this emergent knowledge-based competition has affected a wide spectrum of organizations, it has raised some particularly significant challenges for firms competing internationally. The home-based sources of knowledge and 'ownership advantages' that had long enabled organizations to compete effectively in international markets (Dunning, 1980) are no longer adequate today. Global rivals now wrest competitive initiative by harnessing knowledge from sources in multiple countries in order to generate new product ideas as well as to build manufacturing know-how and technological strength. Indeed, with the increasing globalization of our economy, the ability to transfer and deploy knowledge across borders has become one of the central competitive concerns for many organizations.

There has been a profound evolution in thinking about multinational corporations (MNCs) during the past 10 years. Traditionally, in academic models researchers assumed that ownership-specific advantages were developed at the corporate headquarters and leveraged overseas through the transfer of technology to a network of foreign subsidiaries (Dunning; 1980). As these overseas subsidiaries grew in size and developed their own unique resources, however, it became apparent to many researchers that corporate headquarters were no longer the sole source of 
competitive advantage for the MNC. Scholars developed models such as the heterarchy (Hedlund, 1986) and the transnational (Bartlett \& Goshal, 1989) to reflect the critical role played by many subsidiaries in their corporation's competitiveness, and research attention began to shift toward understanding the new role played by subsidiaries.

A recent flood of FDI into hightechnology regions, like Silicon Valley, suggests that multinationals in the semiconductor industry are using FDI to gain access to local information channels and thus source location-specific knowledge. Almeida and Kogut (1994) studied the diffusion of technological knowledge in the semiconductor industry and found that knowledge remains localized in the USA and particularly in Silicon Valley. Almeida's (1996) study suggests that foreign firms may not be targeting just regions but specific firms in their learning efforts. Out of areas of knowledge important for a firm, technological knowledge is believed to be the most important for the firm's competitiveness. Whether multinational firms go abroad to acquire technological knowledge or contribute to local technological progress, central to the theory of foreign direct investment (FDI), depends in part on the geographic patterns of knowledge distribution. If knowledge is sticky and remains confined within narrow spatial boundaries, plant location serves as an important source of competitive advantage to firms. Firms located in innovative regions have greater access to new technological knowledge than their spatially distant counterparts. To remedy this disadvantage, firms from other countries set up plants in knowledgeintensive regions. Innovative regions therefore serve as magnets to new investment.

As a result of its open door policy, China emerged as the largest recipient of FDI among developing countries beginning in 1992, and has been the second largest recipient in the world since 1993 next only to the US and the largest host of FDI in the world in 2002. FDI flows to China grew from $\$ 3.5$ billion in 1990 to $\$ 52.7$ billion in 2002. At present, more than $80 \%$ of all Fortune 500 companies operate in China. The significance presence of multinational companies in China warrants studying their role in MNCs global network. Historically, and especially in the case of $\mathrm{U} \mathrm{S}$ and Japanese MNCs, the innovation and knowledge creation have been played only by the domestic units. Hence, most of the studies on knowledge creation and innovation focus on firms located in innovative regions, such as U.S.A., Europe, and Japan. Plants located in developing region are believed to exploit the home-based sources of knowledge and 'ownership advantages'. However, the emergence of technological strength in a greater multiplicity of countries suggests that firms located in U.S. and Japan are no longer the only source of innovation. Hence, this study attempts to identify the changing role of Chinese subsidiaries with respect to knowledge sharing in their global network. This paper develops a framework to characterize the knowledge sharingbased different roles that subsidiaries of MNCs may play in China.

\section{Knowledge and Information}

Knowledge is a multifaceted concept with multilayered meanings. Traditional epistemology defines knowledge as 
"justified true belief". It should be noted, however, that while the arguments of traditional epistemology focus on "truthfulness" as the essential attribute of knowledge, for present purposes it is important to consider knowledge as a personal "belief", and emphasize the importance of the "justification" of knowledge. This difference introduces another critical distinction between the view of knowledge of traditional epistemology and that of the theory of knowledge creation. While former naturally emphasizes the absolute, static, and nonhuman nature of knowledge, typically expressed in propositional forms in formal logic, the latter sees knowledge as a dynamic human process of justifying personal beliefs as part of aspiration for the "truth". Although the terms "information" and "knowledge" are often used interchangeably, there is a clear distinction between information and knowledge. According to Machlup (1983), information is a flow of messages or meanings which might add to, restructure or change knowledge. Dretske (1981) offers some useful definition. In his words: Information is the commodity capable of yielding knowledge, and what information a signal carries is what we can learn from it. Knowledge is defined with information-produced or sustained belief, but the information a person receives is relative to what he or she already knows about the possibilities at the source. In short, information is a flow of messages, while knowledge is created and organized by the very flow of information, anchored on the commitment and beliefs of its holder.

One dimension of knowledge is the distinction between two types of knowledge- "tacit knowledge" and "explicit knowledge". As Michael Polanyi (1966) put it, "We can know more than we can tell". Knowledge that can be expressed in words and numbers only represents the tip of the iceberg of the entire body of possible knowledge. Explicit or codified knowledge refers to knowledge that is transmittable in formal, systematic language. On the other hand, tacit knowledge has a personal quality, which makes it hard to formalize and communicate. Tacit knowledge is deeply rooted in action, commitment, and involvement in a specific context. In Polanyi's words, it "indwells" in a comprehensive cognizance of the human mind and body. Tacit knowledge involves both cognitive and technical elements.

\section{Framework for modeling subsidiary strategic role}

\section{Global and local knowledge}

It has been suggested that the multinational enterprise engages in the synthesis and integration of knowledge which either exist, or can be created, or can be acquired, which is originally localized and which the enterprise seeks to apply more broadly. This activity may be described as the globalization of local knowledge, but there are several distinct approaches that firms may adopt. In order to do so, it will be helpful to provide clear interpretations of the terms 'local knowledge' and 'global knowledge' for the present research formulation. These terms are used to indicate the spatial availability of knowledge within the corporation. Thus, local knowledge has limited availability within the firm and is typically confined to one place. This may often be knowledge within an operating 
subsidiary, perhaps concerning local market conditions or possibly a technique or process that has been developed locally. However, the term may equally refer to knowledge that is confined to the administrative headquarters of a corporation. Examples might include knowledge of particular strategic plans such as expansions, mergers, acquisitions or disposals, as well as more general know-how concerning corporate finance expertise in multinational managing.

The term global knowledge is used to indicate knowledge that is generally available across the corporation, accessible to all operating subsidiaries, as well as to the administrative centre. Global knowledge is available to all within the firm, the point to emphasize being the accessibility of knowledge rather than its location. Access depends on factors that are not solely spatial, although spatial proximity may often be important. Access to knowledge depends on a number of factors, including awareness of its existence and potential, the presence of channels for communicating knowledge and the absorptive capacity (Cohen and Levinthal, 1990) of the potential users. Past studies have shown the link between stickiness of innovation-related information and the locus of innovation. Von Hippel (1994) characterizes the costs of transferring knowledge from one place to another in terms of "sticky information" and draws a strong relationship between sticky information and the locus of problem solving. The sticky information hypothesis begins with the observation that information is often costly to transfer from place to place. In 1994, Von Hippel hypothesized that information transfer costs would have an impact on the locus of innovation, and that innovation-related problem-solving would tend to be carried out at the site of costly-totransfer information utilized by the problem-solvers. Hence, what matters most is the accessibility of knowledge rather than its location. The stickiness of a given unit of information in a given instance is defined as the incremental expenditure required to transfer that unit of information to a specified locus in a form usable by a given information seeker. Tacitness, context and complementary knowledge are key dimensions of this cost.

\section{Strategy-active subsidiary}

The relation between global and local knowledge provides the basis for the theory of the creative subsidiary or of subsidiary strategies, as distinct from a single, centralized MNE strategy. To some extent, the idea of subsidiary initiatives is set up against a straw man, that of the centralized, single centre of control hierarchical MNE. However, there is virtue in looking at the MNE subsidiary as the interface between two knowledge communities; the firm itself and its local science base. Thus, MNE subsidiaries can become 'knowledge brokers' and form distinctive competencies. Such organizational strengths of subsidiaries can be measured by internal factors such as capabilities and patents residing in the unit and in their business network relationships (Forsgren et al., 1999).

The differences in subsidiary strategic context can be captured by focusing on the magnitude of knowledge exchange in which a subsidiary engages as well as nature of involvement in knowledge 
exchange (user/contributor) with the global knowledge base of the corporation. If these two factors are combined, then any MNC's subsidiary can be arrayed along the following twodimensional space; (a) the extent to which the subsidiary uses the global knowledge base of the corporation and (b) the extent to which the subsidiary contributes to the global knowledge base of the corporation. Contribution and use of knowledge do not necessarily mean knowledge flow, because due to information transfer cost some knowledge remain as sticky, and the innovation-related problem-solving tend to be carried out at the site of costly-totransfer information utilized by the problem-solvers. Thus, as depicted in Fig. 01, in terms of knowledge use/contribution patterns, four generic subsidiary roles can be defined: Global contributor (Innovator) (high contributor, low user), Active (Integrated) Players (high contributor, high user), Exploiter (low contributor, high user), and Independent Player (Local Innovator) (low contributor, low user).

The approach of the present study represents something of a break with existing literature because this has moved away from conceptualizing unidirectional knowledge flows (Gupta and Govindarajan, 1991,1994, 2000; Foss and Pederson, 2000). Gupta and Govindarajan (1991) considered knowledge flow within MNC and defined knowledge flow as the transfer of either expertise or external market data. These researchers overlooked the tacit nature and stickiness of knowledge. The information transfer costs would have an impact on the locus of innovation, and that innovation-related problem-solving would tend to be carried out at the site of costly-totransfer information utilized by the problem-solvers. The emphasis of this study is particularly the subsidiary ability to create value from localized knowledge, hence, whether it is made available and accessible to all within the firm rather than its location.

\section{METHODOLOGY}

In this study, a pilot-tested questionnaire, addressed to the CEO was administered to 856 subsidiaries of multinational companies in China, from August, to December, 2004. Data analysis was confined to the profile of the 38 responded companies due to low response. Responded companies were from 5 countries; U.S., U.K., Sweden, Germany, and Japan. In all cases, standard well-established research instruments with minor changes in wording to adapt the instrument to the multinational context were used. Given below are details pertaining to how the two dimensions -i.e. classification of subsidiaries in terms of strategic roles based on knowledge contribution and use- were operationalized by ten main variables. 


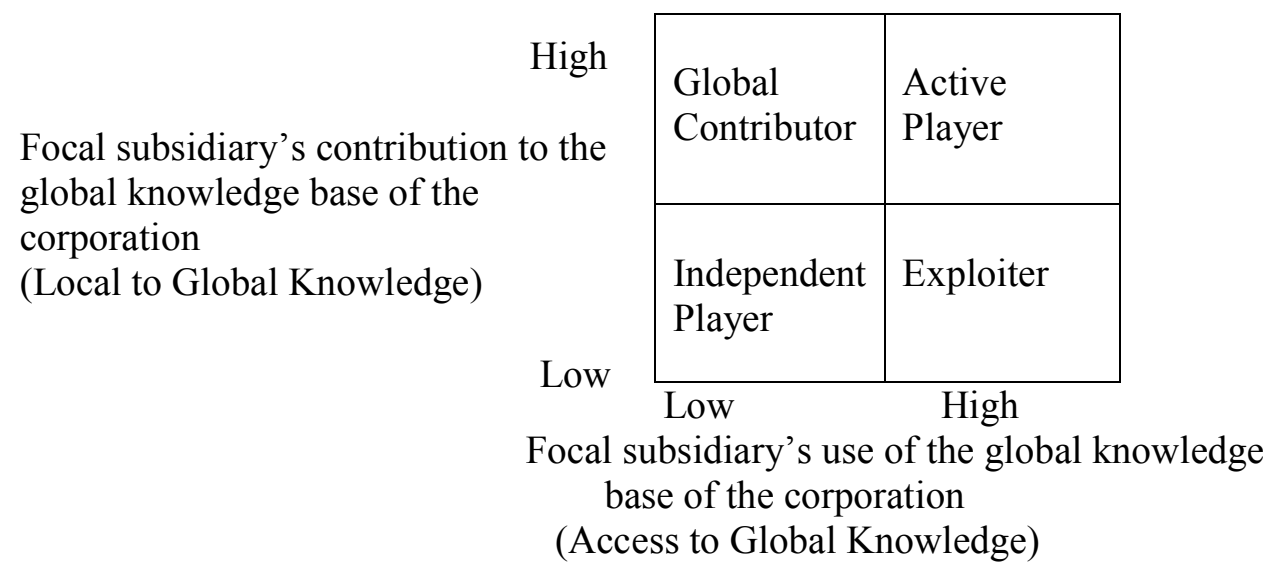

Figure 01: Variations in Subsidiary Strategic Contexts: A Local - Global Knowledge Based Framework

Each subsidiary head was asked to complete a ten-item instrument for each of four knowledge exchange (within or outside the focal subsidiary) context: (1) contribution of knowledge and skills from the focal subsidiary to the parent company; (2) contribution of knowledge and skills from the focal subsidiary to peer subsidiaries; (3) use of knowledge and skills from the parent company to the focal subsidiary; (4) use of knowledge and skills from peer subsidiaries to the focal subsidiary. The ten items pertained to the following different types of knowledge and skills that might be exchanged among various units: (1) research and development; (2) product designs; (3) process designs; (4) marketing and sales; (5) logistics or distribution; (6) packaging design and technology; (7) purchasing know-how; (8) Management systems and practices; (9) collection of competitors data; (10) collection of customers data. For each of 40 items, the respondents were asked to indicate on a five-point Likert scale, ranging from "no use at all" to a " a very great deal", the extent of knowledge exchange in which the focal subsidiary is engaged.

Responses were first averaged across the ten items for each type of knowledge exchange context. Then, the two types of knowledge contribution measures to the parent and to peer subsidiaries were combined to yield a composite measure of knowledge contribution from the subsidiary. Similarly, the two types of knowledge access measures from the parent and from peer subsidiaries were combined to yield a composite measure of knowledge access by the focal subsidiary. In order to contrast the difference between concepts of knowledge sharing and knowledge flow, each subsidiary was asked "Has your subsidiary carried out a innovationrelated problem solving activity of parent or other corporate units at the site of your subsidiary?". This can verify the idea that subsidiary can contribute to corporate knowledge base not only with its knowledge that can flow but also with its sticky information. It was deemed interesting to classify these strategies according to the 'generic strategies' 


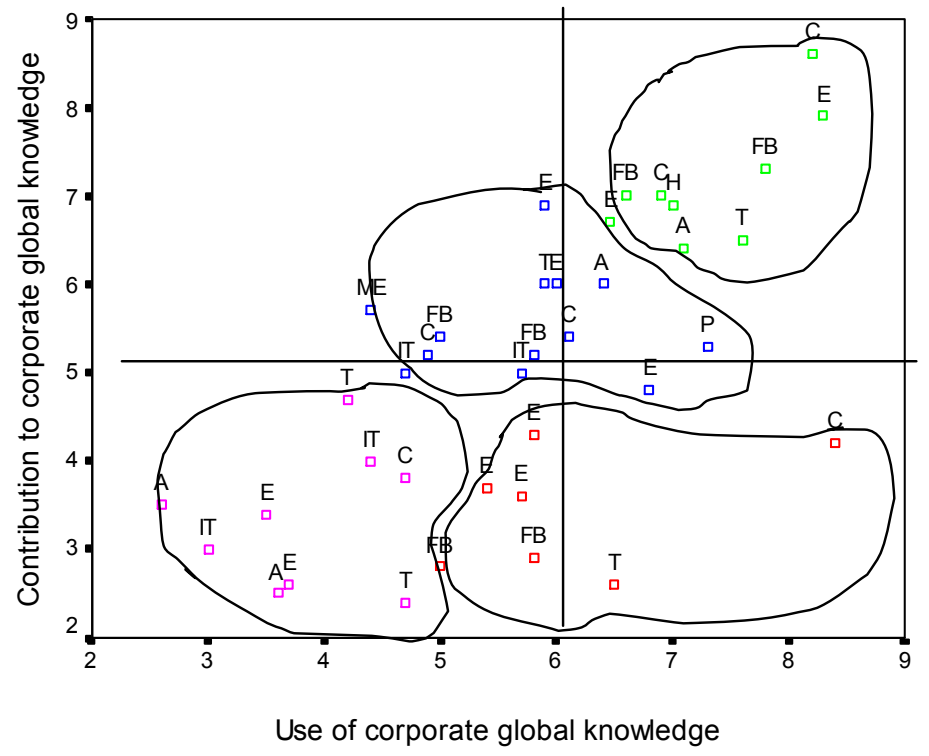

Figure 02: Strategic Map of Chinese Subsidiaries of Multinationals. Industries: A: Automobile; C: Chemical E: Electronic; FB: Food \& Beverages; H: Home \& Personal Care; IT: Information Technology; ME: Mechanical Engineering; P: Pharmaceutical; T: Telecommunication

Table 01: Cluster analysis

\begin{tabular}{|c|c|c|c|c|c|c|}
\hline \multicolumn{3}{|l|}{ Factor } & $\begin{array}{l}\text { Inter-group } \\
\text { Variation }\end{array}$ & $\begin{array}{l}\text { Intra-group } \\
\text { variation }\end{array}$ & F-value & $\mathrm{p}$ level \\
\hline \multicolumn{3}{|c|}{$\begin{array}{l}\text { 1. Knowledge Contribution } \\
\text { 2. Knowledge Use }\end{array}$} & $\begin{array}{l}29.119 \\
18.895\end{array}$ & $\begin{array}{l}0.457 \\
0.701\end{array}$ & $\begin{array}{l}63.698 \\
26.957\end{array}$ & $\begin{array}{l}0.000 \\
0.000\end{array}$ \\
\hline Group & $\begin{array}{l}\text { Number } \\
\text { of firms }\end{array}$ & Factor & $\begin{array}{l}\text { Minimum } \\
\text { value }\end{array}$ & $\begin{array}{l}\text { Maximum } \\
\text { value }\end{array}$ & $\begin{array}{l}\text { Average } \\
\text { value }\end{array}$ & $\begin{array}{l}\text { Standard } \\
\text { deviation }\end{array}$ \\
\hline \multirow[t]{2}{*}{1} & 7 & Contribution & 2.60 & 4.30 & 3.44 & 0.6852 \\
\hline & & Use & 5.00 & 8.40 & 6.08 & 1.1171 \\
\hline \multirow[t]{2}{*}{2} & 9 & Contribution & 6.40 & 8.60 & 7.14 & 0.7055 \\
\hline & & Use & 6.47 & 8.30 & 7.32 & 0.6723 \\
\hline \multirow[t]{2}{*}{3} & 13 & Contribution & 4.80 & 6.90 & 5.53 & 0.5750 \\
\hline & & Use & 4.40 & 7.30 & 5.76 & 0.8352 \\
\hline \multirow[t]{2}{*}{4} & 9 & Contribution & 2.40 & 4.70 & 3.32 & 0.7726 \\
\hline & & Use & 2.60 & 4.70 & 3.82 & 0.7378 \\
\hline
\end{tabular}


discussed above. Thus a real taxonomy could be obtained, not a mere typology, for it would be based on empirically based dimensions. To obtain such a taxonomy, a cluster analysis was performed, following ' $\mathrm{K}$ - means' algorithm to identify the knowledge sharing -based strategic role that a particular subsidiary can be said to be playing within its parent MNC's global network of subsidiaries (see Figure 02.). Median split along these two composite measures were used to demarcate the each domain.

\section{RESULTS AND DISCUSSION}

\section{Key dimensions of knowledge sharing} strategy

According to the measures developed, knowledge sharing strategy of Chinese subsidiaries of MNCs was ascertained on two indicators: (1). Degree of contribution to the global knowledge base of the corporation. The mean score is 2.5 , which indicates that subsidiaries of MNCs present in China fairly contribute intellectual resources to their global network. (2) Degree of use of global knowledge base of the corporation. The mean score is 2.86, which states that Chinese subsidiaries of MNCs utilize extensively the global knowledge base of the corporation as well. The correlation coefficient of the two dimensions, 0.676 , is significant at 0.01 level. This indicates that knowledge sharing strategy of Chinese subsidiaries of MNCs can be established on the contribution to and use of corporate global knowledge scale (Figure 02.).

Table 01 shows the results of the cluster analysis. It was found that there is a good four- group clustering, for variance among the group is far larger than variance within the groups. Of these four groups the first, composed of 7 firms, with high use and low contribution, could be close to the 'Exploiters' strategy group outlined above, although some of them fall near 'Independent Players' strategy type. These subsidiaries engage in little knowledge creation of its own and relies heavily on knowledge from either the parent or peer subsidiaries. This role is the theoretical observe of the Global Contributor role as is illustrated by the fact that, in the early histories of most MNCs where the domestic unit served as the Global Contributor, the role of foreign units automatically became that of serving as Exploiters. This strategy type is inline with White and Polynter's (1984) "Miniature Replica", and Jarillo and Martinez's (1990) "Autonomous" type. The second group is made up of 9 firms. Contribution to and use of global knowledge base of the corporation are high. This group belongs to the 'Active Players' strategic type. The Active Player role is similar to the Global Contributor role because it also implies a responsibility for creating knowledge that can be utilized by other subsidiaries. However, unlike the Global Contributor, an Active Player subsidiary is not selfsufficient in the fulfillment of its own knowledge needs. This strategy type is inline with White and Polynter's (1984) "Global Mandate", Jarillo and Martinez's (1990) "Active" type and Bartlett and Ghoshal's (1986) "Strategic Leader". The third group contains 13 firms. These are high contributors and low users of global knowledge base of the corporation. According to the results of cluster analysis, these firms are close 
to 'Global Contributors' strategic group, although some of them belong to 'Active Players', 'Exploiters' and Independent Players' strategic groups. In the Global Contributor role, the subsidiary serves as the fountainhead of knowledge for other units. This strategy type is inline with Jarillo and Martinez's (1990) "Receptive" strategy type. Historically, and especially in the case of $\mathrm{U} \mathrm{S}$ and Japanese MNCs, this role has been played only by the domestic units. However, as documented by Bartlett and Ghoshal (1989), Harrigan (1984), and Ronstadt and Kramer (1982), this is changing. Arguably, a major catalyst behind this change has been the emergence of technological strength in a greater multiplicity of countries (Port, 1990). The fourth group is composed of 9 firms, with low contribution to and low use of global knowledge. This group follows more 'Independent' type strategy. The Independent Player's role implies that the subsidiary has almost complete local responsibility for the creation of relevant know-how in all key functional areas; however, this knowledge is seen as too idiosyncratic to be of much competitive use outside of the country in which the Independent Player is located. Traditional multidomestic MNCs have consisted almost entirely of subsidiaries with Independent Player roles. However, subsidiaries with Independent Player role can exist also in transnational or simple global MNCs. It is noteworthy that some firms in the same industry tend to fall close while some having different strategies.

\section{CONCLUSIONS}

Multinationals by their very nature are network firms. They are therefore able to leverage their networks to effectively manage dispersed knowledge assets. In this study, we conceptualized multinational enterprise as an integrative unit for making localized knowledge global. Knowledge base of a MNC was basically categorized into two groups; local and global knowledge according to accessibility of corporate units to the knowledge of the corporation rather than its location. Subsidiaries face competition from within the company and from outside. Knowledge sharing strategies have gained relevance in enhancing firms' competitive performance. It is argued that strategic roles of subsidiaries within the same MNC can differ in terms of magnitude and nature of involvement in sharing with the global knowledge base of the corporation. Based on the knowledge sharing patterns, a four-cell classification matrix was developed to illustrate different strategic roles of subsidiaries. The significant intersubsidiary differences in knowledge sharing patterns were found.

Chinese economy is in a process of strong globalization in which MNCs operating in the country are important participants; more than $80 \%$ of all Fortune 500 companies are in China. It is believed that China attracts large part of FDI due to its huge market and high quality-, low cost- labor. The aim of this study was to identify the relevance of China in terms of knowledge contribution to firms' competitive position, as most studies on this topic focus on innovative region like U.S.A., Europe, and Japan. During their evolution, subsidiaries gain competence and are supposed to play different roles in the MNCs network. This study addressed this question and found that 
Chinese subsidiaries play different roles in knowledge creation and sharing. It was found that out of areas of knowledge concerned, Chinese subsidiaries contribute much knowledge about management systems and practices to the parent, about process designs to peer subsidiaries, and use much knowledge about product designs, and management systems and practices from the parent, and about management systems and practices from peer subsidiaries.

The findings pertaining to Global Contributors and Active Players are quite interesting. Global Contributors engage in high knowledge contribution to the corporation while receiving little knowledge. They are serving as sources of creativity and innovation not just for their own needs but also for the whole corporation. Active Players bear the responsibility for creating knowledge that can be utilized by other subsidiaries. However, unlike the Global Contributor, an Active Player subsidiary is not selfsufficient in the fulfillment of its own knowledge needs. The substantial presence of Global Contributors and Active Players suggest that these firms play the role of participants in the corporate innovative activity rather than the role of absorbers of corporate knowledge and technology. A firm's ability to successfully commercialize a new product depends not only on its own technology strategy, but also on activities performed by a wide range of organizations in its innovation system. The increasingly international flavor of high-technology innovation suggests that innovation systems are becoming global.

\section{References}

Almeida P. and B. Kogut, (1994). "Technology and geography: The location of knowledge and the mobility of patent holders", Huntsman Centre for Global Competition and Innovation, Wharton School, Philadelphia, PA.

Almeida P., (1996). "Knowledge sourcing by foreign multinationals: Patent citation analysis in the U.S. semiconductor industry" Strategic Management Journal, 7, pp. 155-165.

Bartlett C.A. \& S. Goshal, (1986). "Tap your subsidiaries for global reach", Harvard Business Review, November- December, 87-94.

Bartlett C.A. and S. Goshal, (1989). "Managing across borders: the Transnational Solutions", Harvard Business School Press, Boston.

Cohen W.M., and D.A. Levinthal, (1990). "Absorptive capacity: a new perspective on learning and innovation. Adm. Sci. Q. 35, pp.128-152.

Dretske F., (1981). "Knowledge and the Flow of Information”, Cambridge, MA: MIT Press.

Dunning J.H., (1980). "Towards an eclectic theory of international production"” Journal of International Business Studies, Spring-Summer, pp.9-31.

Foss N. J. and T. Pedersen, (2000). "Transferring knowledge in MNCs: The role of sources of subsidiary knowledge and organizational context", J. Int. Mgt., pp. 49-67.

Forsgren M. et. al. (1999). "Accounting for the strength of MNC subsidiaries: the case of Foreign owned firms in Denmark", Int. Bus. Rev., pp. 181-196.

Gupta A K and V. Govindarajan, (1991). "Knowledge flows and structure of control within multinational corporations", Academy of Management Review, 16, 4, pp.768-792. 
Gupta A K. and V. Govindarajan, (1994). "Organizing for knowledge flows within MNCs", International Business Review, pp. 443-457.

Gupta A K. and V. Govindarajan, (2000). "Knowledge flows within multinational corporations", Strategic Management Journal, pp. 473-496.

Harrigan K.R.,(1984). "Innovation within overseas subsidiaries”, J. of Bus. Strategy, 4(4), pp. 47-55.

Hedlund G., (1986). "The modern MNC-A hetearchy. Human Resource Mgt.,25(1), pp 9-35.

Jarillo J.C. and J. L. Martinez, (1990). "Different role for subsidiaries: The case of multinational corporations in Spain", Strategic Management Journal, 11,pp. 501-512.

Machlup F., (1983). "Semantic Quirks in Studies of Information,” In: F. Machlup and U. Mansfield (Eds.) The study of Information, New York: John Wiley.

Polanyi M.,(1966). "Personal knowledge", Chicago, II: The University of Chicago Press.

Port, O. (1990). "Why the US is losing its lead. Business Weak, June, 15, pp. 34-39.

Prahalad C.K. and G. Hamel, (1990). "The core competence of the corporation", Harvard Business Review, 68(3), pp. 79-91.

Quinn J.B.1.,(1992). “Intelligent Enterprise”, New York Free Press.

Ronstadt R. and R. Kramer (1982). "Getting the most out of innovation abroad", Harvard Bus. Rev, 58(2), pp. 94-99.

Stewart T.A., (1997). "Intellectual Capital": The New Wealth of Organization" Currency Doubleday: New York.

Von Hippel E., (1994). "Sticky information and the locus of problem solving: Implications for innovation", Management Science, vol.40, no. 4, April, pp.429-439.

White R.E. and T. A. Polynter, (1984). "Strategies for foreign owned subsidiaries in Canada”, Business Quarterly, Summer, pp.59-69. 